\title{
18-year-old man with cardiomyopathy resulting from isolated left ventricular non-compaction and atrial fibrillation diagnosed for the first time - difficult choices and therapeutic decisions
}

\author{
18-letni mężczyzna z kardiomiopatią z niescalenia mięśnia lewej komory \\ oraz rozpoznanym po raz pierwszy migotaniem przedsionków \\ - trudne wybory i decyzje terapeutyczne
}

Andrzej Jakub Sałacki, Andrzej Wysokiński

Chair and Department of Cardiology, Medical University of Lublin

\section{Abstract}

The article presents the case of an 18-year-old man who underwent ablation with the use of alternating electric current with radio frequency of the accessory pathway due to the Wolff-Parkinson-White syndrome, was diagnosed with cardiomyopathy resulting from left ventricular non-compaction and was admitted to the Cardiac Intensive Care Unit as a result of his first bout of atrial fibrillation. After the first pharmacological cardioversion proved to be ineffective, electrical cardioversion was implemented, successfully restoring sinus heart rhythm. Further difficult decisions regarding the patient's drug therapy will have to be made, especially in the area of oral anticoagulants. After the analysis of the clinical picture, laboratory tests and echocardiography, the decision was made not to introduce oral anticoagulants and continue administration of the acetylsalicylic acid. There are no clear criteria and guidelines regarding the use of oral anticoagulant therapy in the case of cardiomyopathy resulting from left ventricular non-compaction and there are various views on the need of implementing such therapy after the first episode of arrhythmia and on how long it should last, therefore this case needs to be analyzed and discussed.

Key words: pre-excitation syndrome, cardiomyopathy resulting from left ventricular non-compaction, oral anticoagulants

Folia Cardiologica 2016; 11, 4: 338-340

\section{Introduction}

Left ventricular non-compaction (LVNC) is a form of familial cardiomyopathy resulting from disrupted fusion of myocardium trabeculae carneae during intrauterine development [1]. The number of diagnosed instances of LVNC has increased significantly within the last twenty years [2].
According to the European Society of Cardiology, it belongs to the group of unclassified cardiomyopathies [3], whereas, according to the American Heart Association, it is a distinct genetic primary cardiomyopathy [4]. A characteristic trait of LVNC is the presence of non-compacted, in other words excessively trabeculate, left ventricular (LV) myocardium. Layers of non-compacted and compacted LV muscle jointly 
form a characteristic two-layer structure of myocardium [5]. Clinical signs depend on how disrupted the structure is therefore the description included both asymptomatic patients and symptomatic patients with disorders of LV systolic and diastolic functions, various forms of Cardiac arrhythmias or instances of embolism [6]. However, there have been no therapies specifically targeted at LVNC yet and the treatment should incorporate the standards applied in the case of Cardiovascular System disorders, arrhythmias, as well as eliminating the risk of sudden death or embolic complications.

\section{Case report}

An 18-year-old man was transferred from an emergency department to the Cardiac Intensive Care Unit (CICU) as a result of his first bout of atrial fibrillation (AF) lasting from morning (Fig. 1). The patient in 2016 underwent ablation with the use of alternating electric current with radio frequency of the accessory pathway (inferior septal pathway) due to the WPW syndrome diagnosed in 2013. Moreover, he was diagnosed with cardiomyopathy resulting from LVNC.

Physical examination showed abnormal heart action $75-100 / \mathrm{min}$, peripheral pulse deficit, dull and quiet heart sounds. The patient experienced strong heart palpitation. Following the recommendations after ablation, for three month he would take a $150 \mathrm{gm}$ dose of aspirin on a regular basis. Laboratory tests showed the TSH of 0,285 mIU/L, standard $(0.55-4.78)$ in the case of regular peripheral thyroid hormone levels - FT3 and FT4.

The TTE showed that LVEDd was $62 \mathrm{~mm}$. Moreover, the patient had irregular LV muscularis increased LV trabeculation below papillary muscles, segmentally thinned
LV wall in the apex area - a probable LV non-compaction center, heterogeneous echogenicity of interventricular septum and its thickened upper part (13 mm), EF 55\%, SF $\sim 30 \%, 15 \mathrm{~mm}$ scope of mitral annular plane systolic excursion, LA $\sim 35 \mathrm{~mm}$.

Prior to his treatment, unfractionated heparin was administered in the dose of 5 thousand units by intravenous bolus. The authors have considerable experience of using antazoline in the case of paroxysmal atrial fibrillation, thus the therapy began with its intravenous administration in the dose of $100 \mathrm{mg}$. As it turned out to be ineffective, it was administered with potassium, magnesium and Xylocaine added to the multi-electrolyte fluid. The therapy has not produced any results therefore slow intravenous infusion of $150 \mathrm{mg}$ of Amiodarone in $250 \mathrm{ml}$ of $5 \%$ glucose was initiated. Unfortunately, it has not produced any therapeutic effects either. As a result, a decision was made to perform anterolateral electrical cardioversion with $150 \mathrm{~J}$ two-phase current under total intravenous anesthesia. The cardioversion produced the expected results by restoring sinus heart rhythm. Initiation of oral anticoagulant (OAC) therapy introduced after electrical cardioversion proved to be another problematic issue, especially at duty in CICU. Finally, the decision was made to continue using the ASA preparation.

\section{Discussion}

There is a need for an in-depth discussion due to the lack of clear recommendations and guidelines for introducing and using OAC in the case of patients diagnosed with LVNC and patients who due to their basic disease, such as LVNC, also come down with malignant arrhythmias like AF which

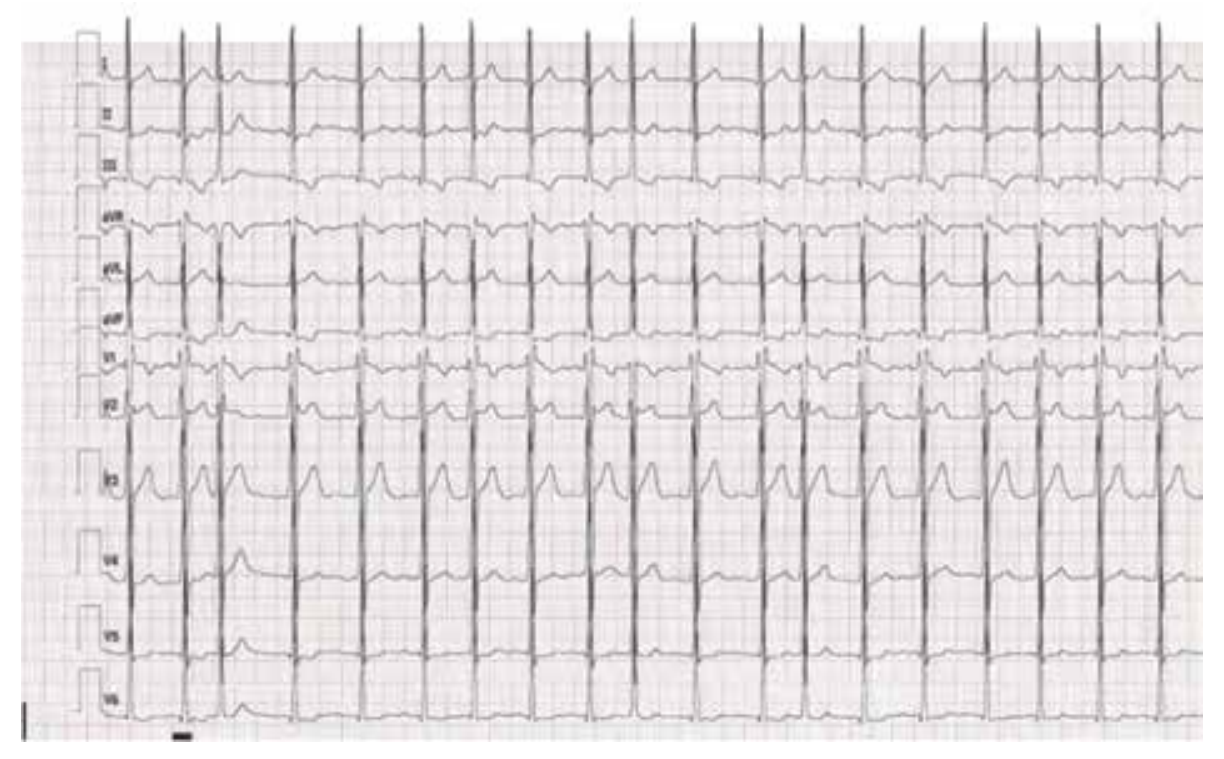

Figure 1. ECG taken upon admission 
sooner or later also require such therapy. In the reported case the TTE did not show any mitral valve defects. Based on the $\mathrm{CHA}_{2} \mathrm{DS}_{2} \mathrm{VASc}$ score, the risk of a stroke and thromboembolic complications was estimated at 0 points. Following the ESC guideline [7] for the year 2012 regarding actions to be taken in the case of AF, a 4-week OAC therapy should be introduced after electrical cardioversion if AF lasts under 48 hours; in the reported case it lasted for several hours.

Previous scientific reports advised to introduce anticoagulants in the case of this form of cardiomyopathy in treatment of all symptomatic patients. It was considered to be particularly important due to a 25-times bigger thromboembolic risk in the group of patients with LVNC [8]. Currently, a less restrictive view is prevailing - it supports the idea that OAC should be considered in the case of patients who have undergone embolic events and patients with other coexisting indications like AF, thrombus in LV or significant LV systolic dysfunction. OAC should not be used on a regular basis in the case of asymptomatic patients with LVNC [9]. Pignatelli et al. [10] have not observed any embolic complications in retrospective analysis of LVNC pediatric population where all patients were administered aspirin. The issue of applying OAC in the case of LVNC is still very controversial and has not been settled yet.

\section{Conflict of interest}

None declared.

\section{Streszczenie}

Przedstawiono przypadek 18 letniego mężczyzny po ablacji prądem zmiennym o częstotliwości radiowej drogi dodatkowego przewodzenia, z powodu zespołu WPW, z rozpoznaną kardiomiopatią z niescalenia mięśnia lewej komory, który w warunkach dyżuru OIOK został przyjęty z powodu rozpoznanego po raz pierwszy w życiu napadu migotania przedsionków. Po nieskutecznej próbie kardiowersji farmakologicznej, konwersję do rytmu zatokowego uzyskano elektrycznie. Jak się okazało trudne decyzje co do dalszej farmakoterapii pacjenta, szczególnie w zakresie doustnego leczenia przeciwzakrzepowego dopiero się zaczęły. Po analizie całokształtu obrazu klinicznego, wykonanego badania echokardiograficznego oraz badań laboratoryjnych nie zdecydowano się na włączenie doustnej terapii przeciwkrzepliwej, utrzymując przyjmowany kwas acetylosalicylowy. Wobec braku jasnych kryteriów i zaleceń dotyczących stosowania doustnego leczenia przeciwzakrzepowego w kardiomiopatii z niescalenia mięśnia lewej komory, różnorodności poglądów co do potrzeby jego włączania po pierwszym epizodzie arytmii oraz czasu jego trwania opisany przypadek zasługuje na analizę i dyskusje.

Słowa kluczowe: zespół preekscytacji, kardiomiopatia z niescalenia mięśnia lewej komory, doustne leczenie przeciwzakrzepowe

Folia Cardiologica 2016; 11, 4: 338-340

\section{References}

1. Borges A.C., Kivelitz D., Baumann G. Isolated left ventricular non-compaction: cardiomyopathy with homogeneous transmural and heterogeneous segmental perfusion. Heart 2003; 89: e21.

2. Captur G., Nihoyannopoulos P. Left ventricular non-compaction: genetic heterogeneity, diagnosis and clinical course. Int. J. Cardiol. 2010; 140: 145-153.

3. Elliott P., Andersson B., Arbustini E. et al. Classification of the cardiomyopathies: a position statement from the European Society of Cardiology Working Group on Myocardial and Pericardial Diseases. Eur. Heart J. 2008; 29: 270-276.

4. Maron B.J., Towbin J.A., Thiene G. et al. Contemporary definitions and classification of the cardiomyopathies. Circulation 2006; 113 : 1807-1816.

5. Miszalski-Jamka K., Głowacki J., Kalarus Z. Niescalenie mięśnia lewej komory - coraz częściej rozpoznawana kardiomiopatia. Kardiochir. Torakochir. Pol. 2012; 1: 106-113.
6. Weiford B.C., Subbarao V.D., Mulhern K.M. Noncompaction of the ventricular myocardium. Circulation 2004; 109: 2965-2971.

7. Wytyczne ESC dotyczące postępowania w migotaniu przedsionków na 2012 rok. Kardiol. Pol. 2012; 70 (Suppl IV): 197-234.

8. Serwa-Stępień E., Barylski M., Banach M. i wsp. Niescalenie mięśnia lewej komory. Kardiol. Pol. 2006; 64: 1126-1131.

9. Oechslin E.N., Attenhofer Jost C.H., Rojas J.R. et. al. Long-term follow-up of 34 adults with isolated left ventricular noncompaction: a distinct cardiomyopathy with poor prognosis. J. Am. Coll. Cardiol. 2000; 36: 493-500.

10. Ilercil A., Barack J., Malone M.A. et al. Association of noncompaction of left ventricular myocardium with Ebstein's anomaly. Echocardiography 2006; 23: 432-433. 